\title{
CALCAREOUS NANNOFOSSILS AND CHEMOSTRATIGRAPHY OF THE EARLY APTIAN OCEANIC ANOXIC EVENT 1A FROM NORTHERN IRAQ
}

\author{
Falah A. Al-Miamary* Omar A. Al-Badrani* and Ali I. Al-Juboury** \\ *Geology Department, College of Science, University of Mosul, Mosul, Iraq \\ -Corresponding author: alialjubory@yahoo.com
}

Received Date: 11 March 2020, Accepted Date: 31 May 2020, Published Date: 24 June 2020

\section{ABSTRACT}

Calcareous nannofossils were documented from the upper part of the Cretaceous Balambo Formation in northern Iraq with the aim of determining an evidence for the Oceanic Anoxic Event. A detailed investigation of the calcareous nannofossils led to the identification of twenty-four species. Regarding these data, Discolithus litterarius (Górka, 1957) was identified at the studied interval with the age of Early Aptian.

Early Aptian assemblages are dominated by nannoconids that drop sharply within the $D$. litterarius nannofossil zone, which may be related to the nannoconid crisis recorded in the Early Aptian in the other parts of the world. This event is coincided by a decrease in $\mathrm{CaCO}_{3}$ content and higher content of the Total Organic Carbon (TOC).

Key words: Aptian, Balambo Formation, Iraq, Nannoconid, OAE1a.

\section{INTRODUCTION}

Oceanic Anoxic Events (OAEs) are intervals in the earth history where depletion in oxygen occurred at depths over a large geographic area. Climatic changes and paleoceanographic conditions during these intervals show major disturbances in the global carbon cycle (Jenkyns, 2010). OAEs are commonly characterized by marine organic matter accumulation (Erbacher et al., 1996). Several OAEs in the Mesozoic Ocean that manifestly caused major chemical change were recorded and included; Early Toarcian (Posidonienschiefer event, TOAE, $\sim 183 \mathrm{Ma}$ ), Early Aptian (Selli event, OAE 1a, 120 Ma), Early Albian (Paquier event, OAE 1b, $\sim 111 \mathrm{Ma}$ ) and Cenomanian-Turonian OAEs (Bonarelli event, C/T OAE, OAE 2, 93 Ma) (Jenkyns, 2010). Furthermore, Early Aptian OAE1a black shale followed by 'nannoconid crisis' and a 'schizosphaerellid crisis' prior to the Toarcian OAE were also recorded. In both OAEs, rapid nannofloral speciation generally exists at $1.5 \mathrm{Ma}$ before the OAE, but without extinctions (Erba, 2004). 
Calcareous nannofossils and chemostratigraphy

In northeastern Iraq, Al-Khafaf (2018) mentioned that the lower part of the Balambo Formation at Azmer area was Early Aptian in age, with an overall decrease in type and abundance of nannofossils that may relate to an Oceanic Anoxic Event OAE1. The studied area lies at the imbricated zone of Iraq which is part of the Zagros belt and characterized by thrust folded structures and over-thrust blocks. Zagros belt is formed as a result of the closure of the Neo-Tethys oceanic basin and late Cretaceous and Cenozoic convergence of the Arabian plate with continental Eurasia (Stöcklin, 1968; Snyder and Barazangi, 1986; Talbot and Alavi, 1996; Stampfli and Borel, 2002).

The Balambo sediments belong to the Arabian Plate Megasequence (AP8) of Late Jurassic 149Ma - Late Cretaceous 92Ma (Sharland et al., 2001), that were deposited in intrashelf basin on a passive continental margin. The Balambo Formation is one of the common marine Cretaceous successions in northern and northeastern Iraq and is divided in its type section in the Sirwan valley near Halabja in northeastern Iraq into two portions; the lower comprises $259 \mathrm{~m}$ thickness of uniform thin-bedded blue ammonite bearing limestone, greenish marl and black shale. Moreover, the upper part with $503 \mathrm{~m}$ thickness consists of thin-bedded globigerinal limestone, passing downwards to grey radiolarian limestone. The age of the Balambo Formation is regarded as Valanginian-Turonian based on biostratigraphicdata (van Bellen et al., 1959; Buday, 1980).

The age of the formation is variable in other sections in Iraq, the lower part of the formation in Azmer anticline east of Sulaimaniya city is ranging from the late Early Hauterivian to Late Aptian based on calcareous nannofossils assemblages (Al-Mutwali and Al-Khafaf, 2019), while the age of the formation extends from Late Valanginian to Late Aptian in Barsarin village (Rawanduz area) at northeastern Iraq (the studied section) based on planktonic foraminiferal data (Al-Mutwali et al., 2018). Therefore, the lower part of the Balambo Formation in Azmer section correlates with the Balambo Formation at the studied section in Barsarin village. The studied section is composed of dark colored limestone and marly limestone in addition to shale intercalations.

In the present work, an attempt is made to follow the nannofossils distribution in the Cretaceous Balambo Formation from Barsarin section (northern Iraq) with the focus on the Early Aptian nannoconid drop which may relate to 'nannoconid crisis along with Total Organic Carbon (TOC) and carbonate $\mathrm{CaCO}_{3}$ content.

\section{MATERIALS AND METHODS}

Fifteen samples within $400 \mathrm{~cm}$ thick of marly limestones, shales and limestones from Barsarin section, northern Iraq (Map 1, Diag. 1), were selected and prepared using the simple smear slide technique for the study of calcareous nannofossils which are studied with a transmitted-light microscope (Optika B-353POL, Italy). The calcareous nannofossils are extracted at the Department of Geology, University of Mosul, Iraq using the method $(\mathrm{H})$, (Armstrong and Brasier, 2005). For the nannofossil slide preparation, small amount of the disaggregated sample is placed in distilled water and a drop of cellosize is added to act as a dispersant. The cover slip is left to dry on a warm hotplate; then the slide and residues are 


\section{Al-Miamary et al.}

allowed to dry at a low temperature away from possible sources of contamination. A cover slip mounted by Canada balsam is put over the residue and left to dry before examining with transmitted light microscope.

Geochemical analysis is focused on seven samples covering the studied part of the OAE1a at Barsarin section. The organic carbon (OC) is analyzed using the compensation method in an elemental analyzer mass spectrometer (EA-IRMS, Thermo Finnigan Flash HT and Thermo Finnigan Delta V Advantage), whereas, $\mathrm{CaCO}_{3}$ content is carried out by Varian 720 -ES ICPOES. Both analyses were done at laboratories of Katholieke University of Leuven (KULeuven, Belgium). Species identification with their occurrence in Iraq is done at Department of Geology, University of Mosul.
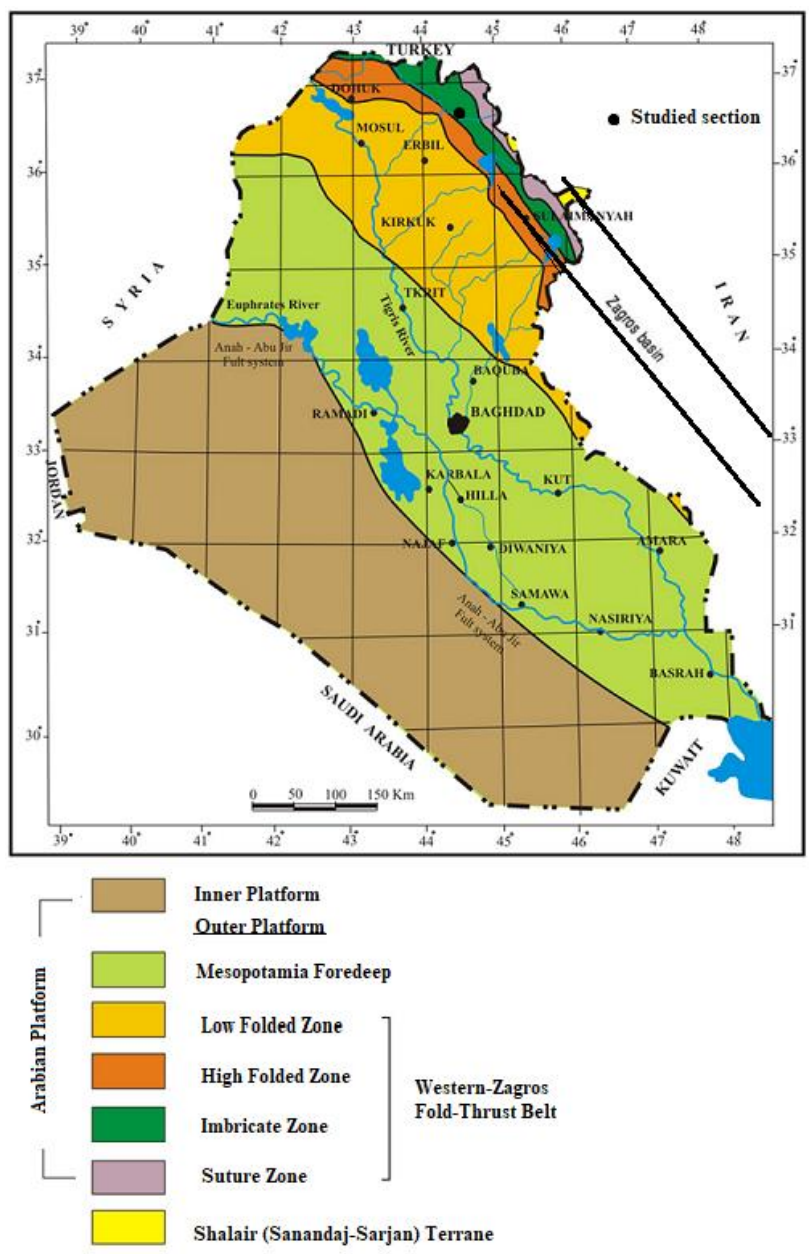

Map (1): Tectonic divisions of Iraq and the location of the studied Barsarin section which is marked with a black circle (after Fouad, 2015). 
Calcareous nannofossils and chemostratigraphy

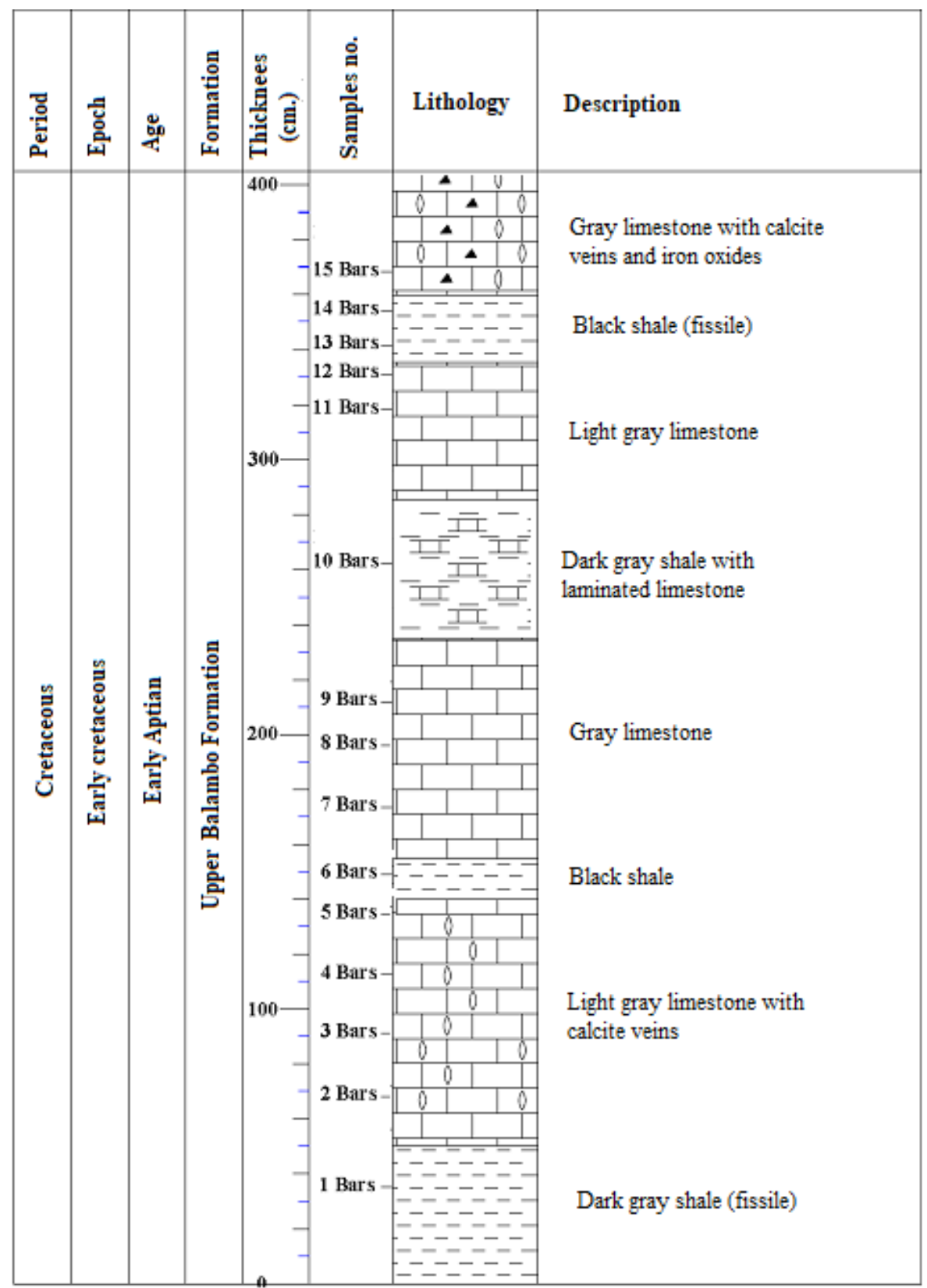

Diagram (1): Lithologic section of the upper Balambo Formation at Barsarin area showing the samples location. 


\begin{abstract}
Al-Miamary et al.
RESULTS

Systematic paleontology

Species identification with their occurrence in Iraq as follows:

Kingdom Protista

Division Chrysophyta

Class Coccolithophyceae

Family Braarudosphaeraceae Deflandre, 1947

Genus Braarudosphaera Deflandre, 1947

Braarudosphaera bigelowii (Gran and Braarud, 1935) Deflandre, 1947 (Pl. 1a)

Description: It is a nannolith with pentagonal outline.

Occurrences: It is recorded from Iraq at Balambo Formation (this study) and from Iraq by $\mathrm{Al}$ -

Badrani (2007) and Al-Badrani and Al-Khashab (2013).

Genus Micrantholithus Deflandre and Fert, 1954

Micrantholithus hoschulzii (Reinhardit, 1966) Thierstein, 1971 (Pl.1b)

Description: It is a nannolithwith of deeply indented sides and gracile, long rays. The height of the pentalith results in a ragged LM appearance.

Occurrences: It is recorded from Iraq at Balambo Formation in this study.

Micrantholithus obtusus Stradner, 1963 (Pl.1c)

Description: It is a nannolith with stellate outline due to shallow indentations in each segment. Occurrences: It is recorded from Iraq at Balambo Formation in this study.

Micrantholithus speetonensis Perch-Nielsen, 1979 (Pl.1d)

Description: It is a nannolith with crenulated outline due to two indentations in each segment.

Occurrences: It is recorded from Iraq at Balambo Formation in this study.

Micrantholithus sp. (Pl.1e)

Description: It is a nannolith with crenulated outline.

Occurrences: It is recorded from Iraq at Balambo Formation in this study.

Family Chiastozygaceae Rood, Hay and Barnard, 1973

Genus Chiastozygus Gartner, 1968

Discolithus litterarius (Górka, 1957) Manivit, 1971 (Pl.1f)

Synonym: Chiastozygus litterarius (Górka, 1957) (GBIF Secretariat, 2019)

Description: It is a Loxoliths with a relatively broad rim and thick, weakly birefringent crossbars. Unicyclic or diffusely bicyclic rim image in XPL.

Occurrences: It is recorded from Iraq at Balambo Formation in this study.
\end{abstract}


Calcareous nannofossils and chemostratigraphy

Genus Zeugrhabdotus Reinhardt, 1965

Zeugrhabdotus embergeri (Nöel, 1959) Perch-Nielsen, 1984 (Pl.1g)

Description: It is a Coccolith with heavily calcified species has a rhomb-shaped, composite bar and very small to no perforations in the central area.

Occurrences: It is recorded from Iraq at Balambo Formation (this study) and by Al-Mamari (2019).

Family Nannoconaceae Deflandre, 1959

Genus Nannoconus Kamptner, 1931

Nannoconus cf. colomii (de Lapparent, 1931) Kamptner, 1938 (Pl.1h)

Description: It is a nannolith with Bulbous basal cavity.

Occurrences: It is recorded from Iraq at Balambo Formation in this study.

Nannoconus kamptneri Brönnimann, 1955 (Pl.1i)

Description: It is a nannolith with Pear-shaped to tapering.

Occurrences: It is recorded from Iraq at Balambo Formation in this study.

Nannoconus cf. Multicadus Deflandre and Deflandre, 1959 (Pl.1j)

Description: It is a nannolith with Tall elongate and cylindrical with one or two constrictions.

Occurrences: It is recorded from Iraq at Balambo Formation in this study; and previously was registered by Al-Badrani (2012).

Nannoconus quadriangulus Deflandre and Deflandre, 1967 (Pl.1k)

Description: It is a nannolith with Short-cylindrical (quadriangular) nannoconids with central cavity that is similar in width to the wall.

Occurrences: It is recorded from Iraq at Balambo Formation in this study.

Nannoconus steinmannii Kamptner, 1931 (Pl.11)

Description: It is a nannolithwith Tapering, pear-shaped nannoconids with narrow central openings (canals) and walls formed from low-angled, narrow cycles.

Occurrences: It is recorded from Iraq at Balambo Formation in this study.

Nannoconus truitti Brönnimann, 1955 (Pl.1m)

Description: It is a nannolith with Barrel-shaped or slightly tapering nannoconids with canal width similar to, or slightly narrower than, the wall.

Occurrences: It is recorded from Iraq at Balambo Formation in this study.

Nannoconus wassallii Brönnimann, 1955 (Pl.1n)

Description: It is a nannolith with Pear-shaped nannoconids with wide central cavities and thick walls; the cavity is two to four times the width of the wall. 


\begin{abstract}
Al-Miamary et al.
Occurrences: It is recorded from Iraq at Balambo Formation in this study.

Nannoconus sp. (Pl.1o)

Description: It is a nannolith with Pear-shaped nannoconids with wide central cavities.

Occurrences: It is recorded from Iraq at Balambo Formation in this study.

Family Podorhabdaceae Noël, 1965

Genus Retecapsa Black, 1971

Retecapsa angustiforata Black, 1971(Pl.1p)

Description: It is a coccolith with a relatively wide central area spanned by an axial cross with one centrally-placed broad lateral bar in each quadrant.

Occurrences: It is recorded from Iraq at Balambo Formation in this study.
\end{abstract}

Family Polycyclolithaceae Forchheimer, 1972

Genus Assipetra Roth, 1973

Assipetra terebrodentarius Roth, 1973 (Pl.1q)

Description: It is a coccolith with Blocky, globular nannoliths formed from six or more complexly intergrown calcite blocks that are joined along broadly radial sutures.

Occurrences: It is recorded from Iraq at Balambo Formation in this study.

Assipetra sp. (Pl.1r)

Description: It is a coccolith with Blocky to globular nannoliths typically formed from intergrown elements that may show radial symmetry.

Occurrences: It is recorded from Iraq at Balambo Formation in this study.

Family Watznaueriaceae Rood, Hay and Barnard, 1971

Genus Watznauria Reinhardt, 1964

Watznaueria barnesae (Black and Barnes, 1959) Perch-Nielsen, 1969 (Pl.1s)

Description: It is a coccolith with Central-area closed or very narrow, with no central area structures.

Occurrences: It is recorded from Iraq at Balambo Formation (this study); previously this species reported from Iraq by Al-Badrani et al. (2012) and Karim et al. (2013).

Watznaueria sp. (Pl.1t)

Description: It is a coccolithwith central-areas that are typically closed or narrow but may be spanned by transverse bar.

Occurrences: It is recorded from Iraq at Balambo Formation in this study.

\title{
Biostratigraphy
}

Depending on the stratigraphic distribution of the recorded species, only one calcareous nannofossils biozone is recorded in this study, which is Discolithus litterarius Biozone, Early Aptian. This biozone is determined by the first occurrence of D. Litterarius to the first occurrence of Prediscosphaera columnata (Stover, 1966; Perch-Nielsen, 1984) that is not 
Calcareous nannofossils and chemostratigraphy

recorded in this study, this biozone is recorded at the upper part of the Balambo Formation within the studied $4 \mathrm{~m}$ out of the total $100 \mathrm{~m}$ thick of the formation in Barsarin area (see Diag. 1). Where correlated with CC7 biozone of Sissingh (1977) it correlates exactly to CC7a aged by Early Aptian (Gradstein et al., 2004), (Diag. 2). The most important and common nannofossil taxa are shown in Diagram (1) and Plate (1).

By the correlation of recorded calcareous nannofossils biozones with regional schemes, it is concluded that the age of studied section is Early Aptian (Diag. 3).

\section{Geochemistry}

Bulk-rock data are presented in Diagram (2). The $\mathrm{CaCO}_{3}$ content decreases from 86.15 to 28.7 that is accompanied by a decline of nannoconid near the Early Aptian nannoconid crisis. The average Total Organic Carbon (TOC) of the analyzed samples content is $0.34 \%$, with the highest values $(0.51 \%)$ recorded at the nannoconids decline interval (Diag. 2).

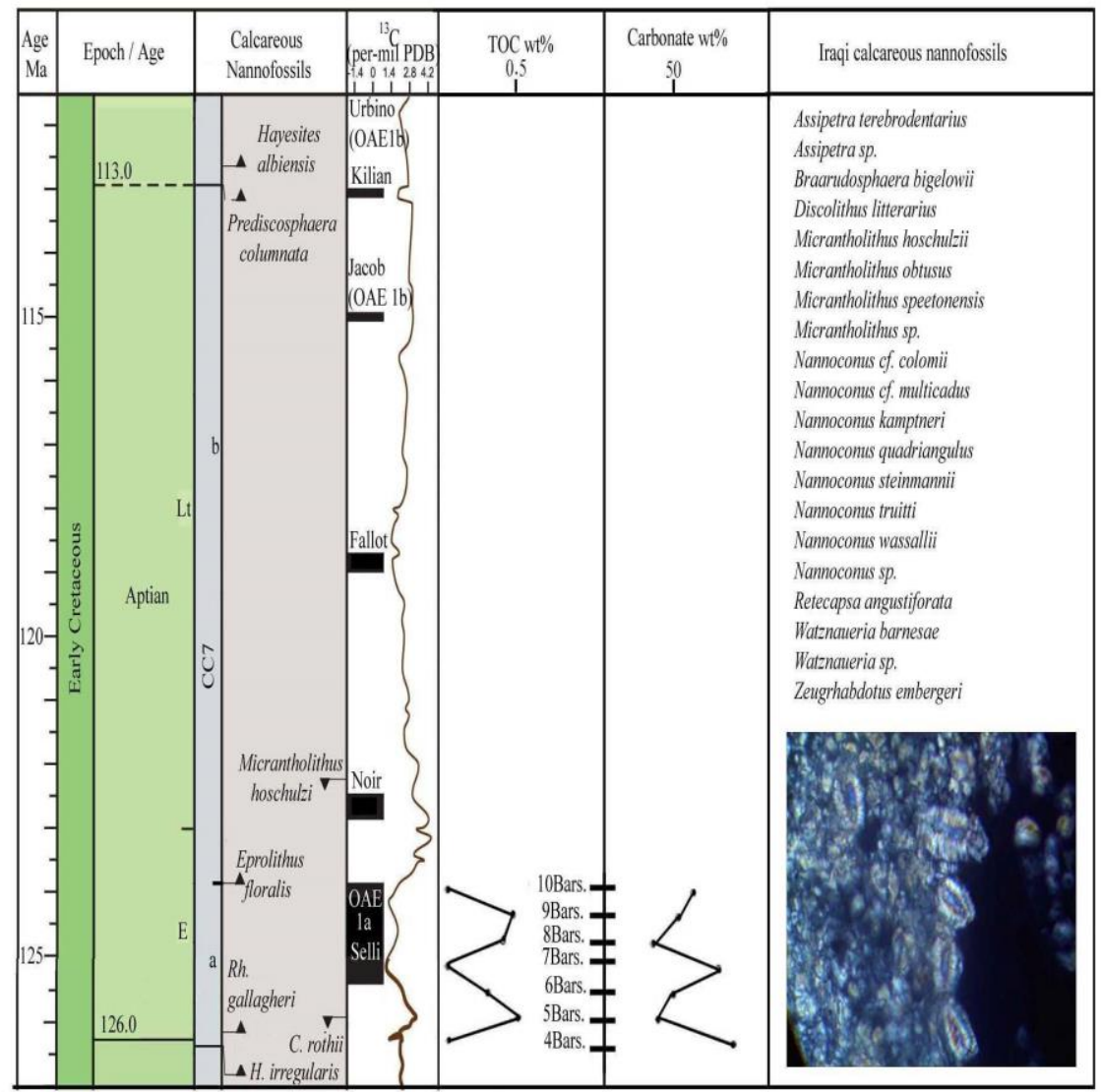

Diagram (2): Calcareous nannofossils and geochemistry data of the investigated Barsarin section (after Gradstein et al., 2012). 


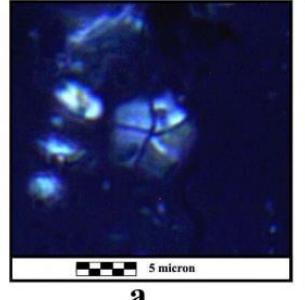

a

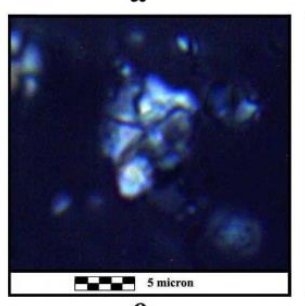

e

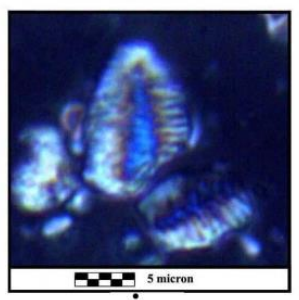

$\frac{{ }^{2}+{ }^{5}}{i}$

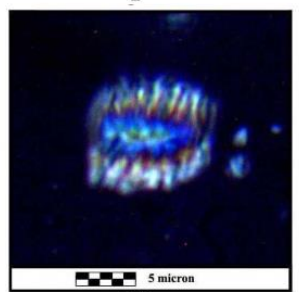

m

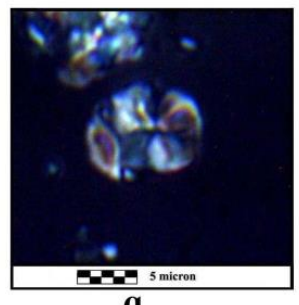

$\mathbf{q}$

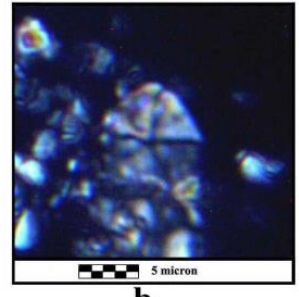

b

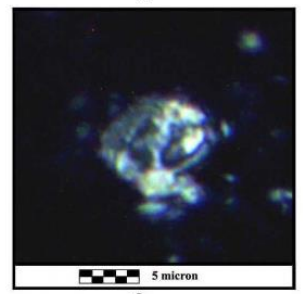

f

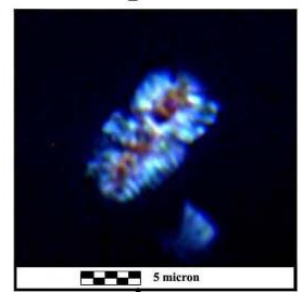

무을

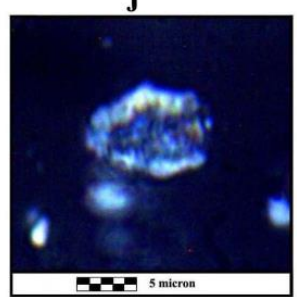

n

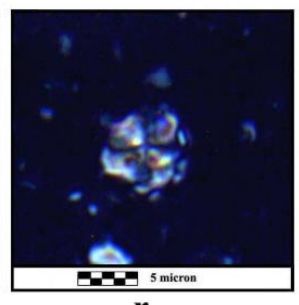

$\mathbf{r}$

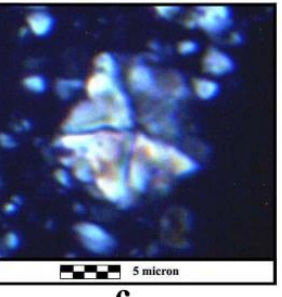

c

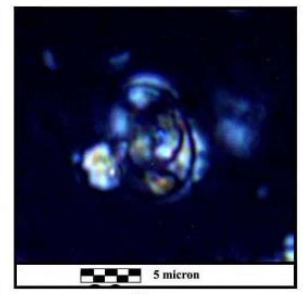

트므무 $5 \mathrm{~m}$

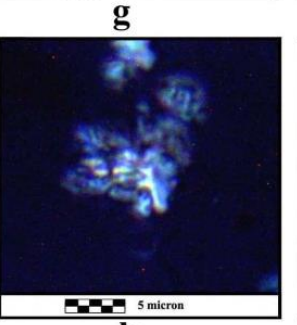

k

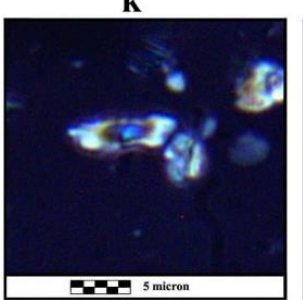

0

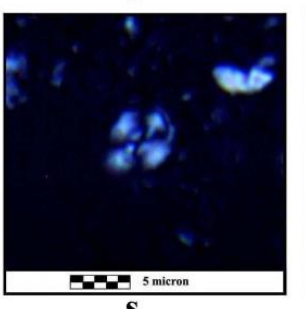

S
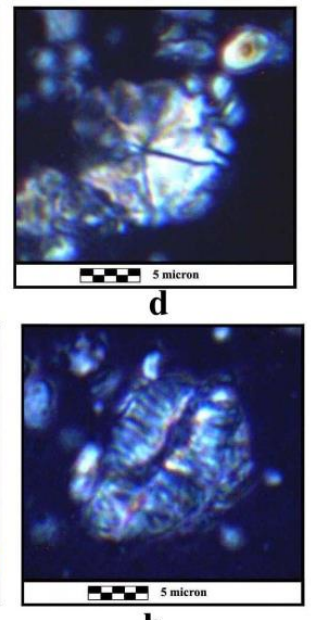

h
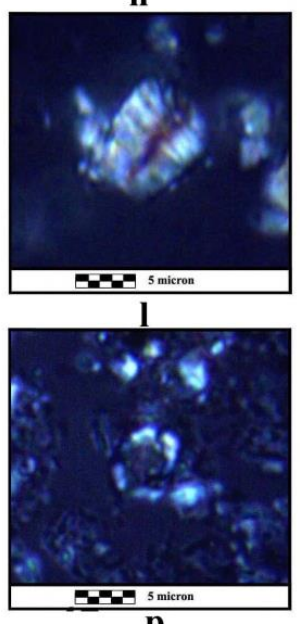

p

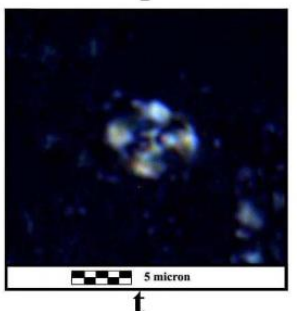

E 5 micron

Plate (1): Cross-polarized light photos of significant calcareous nannofossil taxa from Balambo section. (a) Braarudosphaera bigelowii (Gran and Braarud, 1935) Deflandre, 1947; (b) Micrantholithus hoschulzii (Reinhardit, 1966) Thierstein, 1971; (c) Micrantholithus obtusus Stradner, 1963; (d) , Micrantholithus speetonensis Perch-Nielsen, 1979, (e) Micrantholithus sp., (f) Discolithus 
Calcareous nannofossils and chemostratigraphy

litterarius (Górka, 1957) Manivit, 1971, (g) Zeugrhabdotus embergeri (Nöel, 1959) Perch-Nielsen, 1984, (h) Nannoconus cf. colomii (Delapparent, 1931) Kamptner, 1938, (i) Nannoconus kamptneri Brönnimann, 1955, (j) Nannoconus cf. Multicadus Deflandre and Deflandre, 1959, (k) Nannoconus quadriangulus Deflandre and Deflandre, 1967, (1) Nannoconus steinmannii Kamptner, 1931, (m) Nannoconus truitti Brönnimann, 1955, (n) Nannoconus wassallii Brönnimann, 1955, (o) Nannoconus sp., (p) Retecapsa angustiforata Black, 1971, (q) Assipetra terebrodentarius Roth, 1973, (r) Assipetra sp., (s) Watznaueria barnesae (Blackand Barnes, 1959) Perch-Nielsen, 1969, (t) Watznaueria sp.

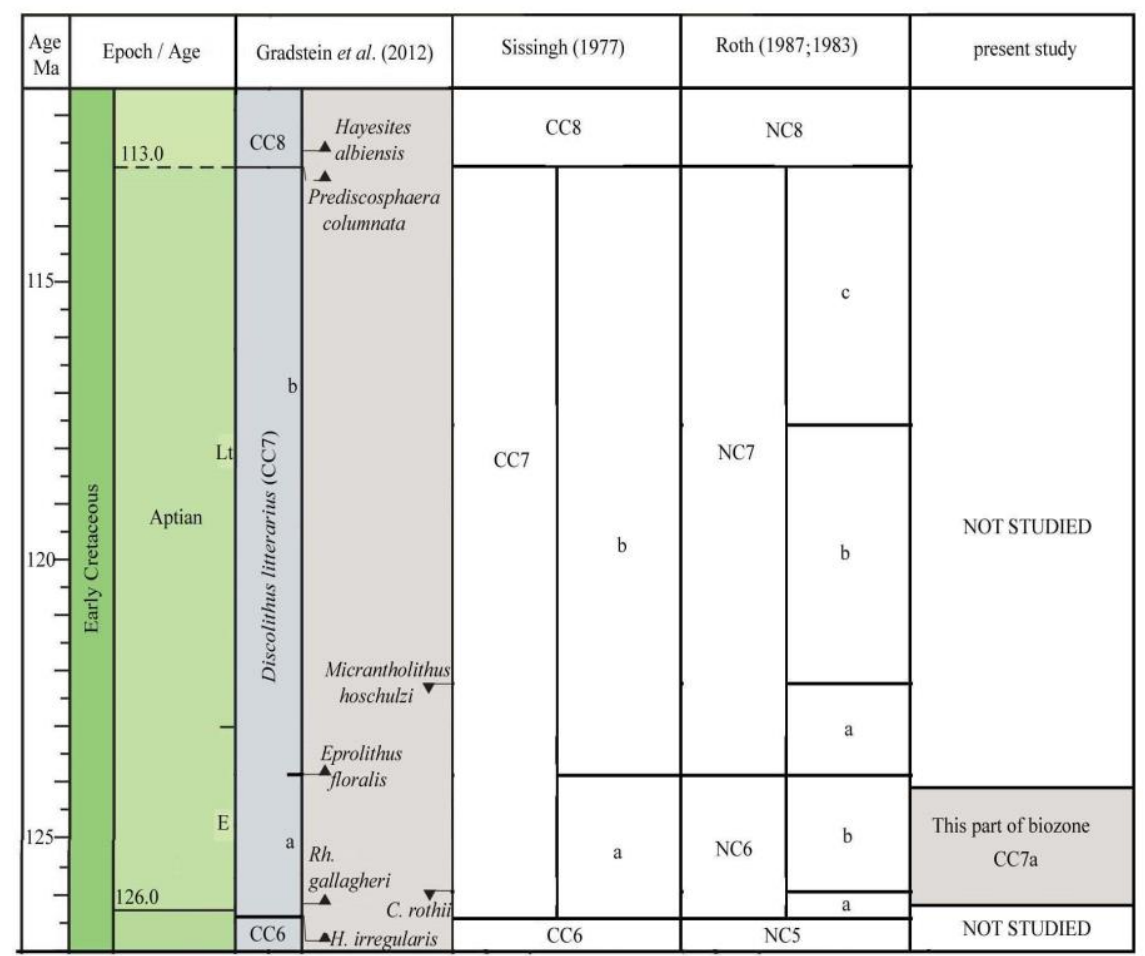

Diagram (3): Correlation of the recorded calcareous nannofossils biozones with regional schemes.

\section{DISCUSSION}

Nannoconid crisis existed during the Late Barremian and Early Aptian (126 to $122 \mathrm{Ma}$ ) on the carbonate rock-forming organisms (nannoconids) and culminated during the OAE1a (Mutterlose and Bottini, 2013). A virtual absence of this calcareous nannoplankton in the Early Aptian may experience a crises called "nannoconid crisis" (Erba, 1994). This absence was recovered later in Late Aptian (Diag. 2) without extinctions but the widespread nature of 


\begin{abstract}
Al-Miamary et al.
this event suggested a global factor. This crisis is recorded within the Discolithus litterarius nannofossil zone (Diag. 2).

A synchronous acme event of the genera Braarudosphaera Deflandre, 1947 and Nannoconus Kamptner, 1931in this section was close to the top of Early Aptian boundary as a result of shallowing of the studied interval. Morphometric data revealed dwarfing trends in the species Watznaueria barnesiae, (see Plates 1-r, s) which may suggest a possible productivity control due to increasing in the nutrient input (Mahanipour et al., 2019). The above mentioned species is also considered as an opportunistic species that are related to more stressful conditions (Aguado et al., 2016; Mahanipour et al., 2019).
\end{abstract}

Early Aptian assemblages are dominated by nannoconids with minor contributions from other nannofossil taxa. Nannoconids are robust taxa so their presence without the presence of other taxa might be the result of diagenesis (Mahanipour et al., 2019). The abundance of nannoconids drops sharply within the Discolithus litterarius nannofossil zone.

The Early Aptian "nannoconid crisis" was followed by a short interval virtually barren of nannoconids and dominated by other nannofossils, only later did a return of nannoconids mark the Late Aptian N. truittii (Erba, 1994, see Diagram (2), present study). The studied Early Aptian assemblages are dominated by nannoconids that drop sharply within the Discolithus litterarius nannofossil zone, which may be related to nannoconid crisis recorded in Early Aptian. This work is supported by geochemical data illustrating that this event is accompanied with decrease in $\mathrm{CaCO}_{3}$ content and higher content of Total Organic Carbon (TOC) similar to those recorded in many regions in the world and specially at Zagros Basin in Iran (Mahanipour et al., 2018, 2019) giving an evidence of global change during this time, like those of Early Cretaceous chalk of the North Sea (Mutterlose and Bottini, 2013). Change in lithology to marls is followed by a decline in nannoconid accompanied by an increase in TOC (Diag. 2).

The abundance trends, palaeoenvironmental and morphological changes among Mesozoic calcareous nannofossil have been widely studied worldwide (Williams and Bralower, 1995; Erba, 1994, 2004; Mutterlose and Ruffell, 1999; Lees, 2002; Bornemann et al., 2003; Mattioli et al., 2004).

Braarudosphaera and Nannoconus are generally common in Early Cretaceous sediments opposite to the Late Cretaceous which is not common (Lees, 2002); the Braarudosphaera is an extant taxon in recent seas, but Nannoconus became extinct in the Late Campanian, making palaeoecological inferences more difficult for this latter genus. Recent and fossil Braarudosphaera are typically restricted to shelf, and their distributions must be influenced by some aspect of the neritic environment because the planktonic life in seas. However, Nannoconus have been studied in details in the Lower Cretaceous (Roth and Krumbach, 1986; Mutterlose, 1989, Busson and Noël, 1991; Erba, 1994). Nannoconus was recorded and widely distributed in the marginal basins of the past oceanic ecosystem (Mutterlose, 1989, 1992; Street and Bown, 2000). This distribution pattern has led to a range of explanations 
concerning their biology and paleobiology, but most have noted the link with tropical paleoenvironments (Roth and Krumbach, 1986; Mutterlose, 1989; Bown, 2005).

The paleoecology of nannoconoids suggested that they were adapted to oligotrophic environments; the decline of nannoconid abundances in the Oceanic Anoxic Event successions commonly is accompanied with an inverse relationship between nannoconid and coccolith abundances (Busson and Noël, 1991; Coccioni et al., 1992; Erba, 1994; Watkins et al., 2005). However, Cunha and Shimabukuru (1997) reported alternating Nannoconus and Braarudosphaera-rich horizons and attributed these to eutrophic conditions, a feature also recorded in the black shales of the Albian OAE1b in France (Kennedy et al., 2000; Herrle, 2003).

\section{ACKNOWLEDGMENTS}

The work is a part of $\mathrm{Ph} \mathrm{D}$ work done by the first author. The authors express their thanks to the University of Mosul, College of Sciences, Department of Geology for their help in providing the available facilities leading to improve the quality of this study, Thanks also are due to Dr. Azam Mahanipour (Shahid Bahonar University of Kerman, Iran) for her fruitful comments and suggestions.

\section{LITERATURE CITED}

Aguado, R., Reolid, M. and Molina, E. 2016. Response of calcareous nannoplankton to the Late Cretaceous Oceanic Anoxic Event 2 at Oued Bahloul (central Tunisia) Palaeogeography, Palaeoclimatology, Palaeoecology, 459: 289-305.

Al-Khafaf, I. H. 2018. Biostratigraphy and depositional environment of Balambo Formation (Lower-Upper Cretaceous) in Azmer Anticline Northeastern Iraq, unpublished Ph. D. Thesis, University of Mosul, College of Science, Geology Department, 102pp.

Al-Mutwali, M. M. and Al-Khafaf, E. H. 2019. Calcareous nannofossils biostratigraphy of the Lower Part of Balambo Formation (Lower Cretaceous) in Azmir Anticline Northeastern Iraq. Iraqi National Journal of Earth Sciences, 19: 19-38.

Al-Mutwali, M. M., Al-Banna, N. Y. and Al-Abbasi, M. W. 2018. Biostratigraphy of Upper Valanginian-Upper Aptian Balambo Formation near Barsarin village in Rawanduz Area, Northeastern Iraq. Iraqi National Journal of Earth Sciences, 18 (2):1 -12.

Armstrong, H. and Brasier, M. 2005. Microfossils, Blackwell Publishing, 296pp.

Bornemann, A., Aschwer, U. and Mutterlose, J. 2003. The impact of calcareous nannofossils on the pelagic carbonate accumulation across the Jurassic-Cretaceous boundary. Palaeogeography, Palaeoclimatology, Palaeoecology, 199: 187-228.

Bown, P. R. 2005. Early to Mid-Cretaceous calcareous nannoplankton from the northwest Pacific Ocean (ODP Leg 198). In: Bralower, T. J., Premoli Silva, I. And Malone, M. J. 
Al-Miamary et al.

(Eds.), Proc. ODP, Scientific Research, 198. Available at http://wwwodp.tamu.edu/publications/198_SR/103/103.htm

Buday, T. 1980.The Regional geology of Iraq. Vol. 1, Stratigraphy and Paleogeography. SOM, Baghdad, 445pp.

Busson, G. and Noël, D. 1991. Les nannoconides indicateurs environnementaux des oceans et mers epicontinentales du Jurassique terminal et du Cretace inferieur. Oceanologica Acta, 14: 333-356.

Coccioni, R., Erba, E. and Premoli Silva, I. 1992. Barremian- Aptian calcareous plankton biostratigraphy from the Gorgo Cerbara section (Marche, central Italy) and implications for plankton evolution. Cretaceous Research, 13: 517-537.

Cunha, A. A. S. and Shimabukuro, S. 1997. Braarudosphaera blooms and anomalous enrichments of Nannoconus: Evidence from the Turonian South Atlantic, Santos Basin, Brazil. Journal of Nannoplankton Research, 19(1): 51-55.

Erba, E. 1994. Nannofossils and superplumes: The Early Aptian "nannoconid crisis". Paleoceanography, 9 (3): 483-501.

Erba, E. 2004. Calcareous nannofossils and Mesozoic oceanic anoxic events.Marine Micropaleontology, 52: 85-106.

Erbacher, J., Thurow, J. and Littke, R.1996. Evolution patterns of radiolaria and organic matter variations: A new approach to identify sea-level changes in Mid-Cretaceous pelagic environments. Geology, 24: 499-502.

Fouad, S. F. A. 2015. Tectonic map of Iraq, scale 1: 1000 000, $3^{\text {rd }}$ edition. Iraqi Bulletin of Geology and Mining, 11: 1-7.

GBIF Secretariat 2019. GBIF Backbone Taxonomy. Checklist dataset https://doi.org/10.15468/39omei accessed via GBIF.org on 2020-05-24.

Górka, H. 1957. Les coccolithophorides du Maestrichtien superieur de Pologne. Acta Palaeontologica Polonica, 2: 235-84.

Gradstein, F. M., Ogg, J. G. and Smith, L. J. 2004. A new geologic time scale, with special reference to Precambrian and Neogene. Episodes, 27(2): 83-100.

Gradstein, F. M., Ogg, J. G., Schmitz, M.D. and Ogg, G. M. 2012. The Geologic Time Scale 2012, Elsevier, 1000 pp. 
Herrle, J. O. 2003. Reconstructing nutricline dynamics of Mid- Cretaceous oceans: evidence from calcareous nannofossils from the Niveau Pacquier black shale (SE France). Marine Micropaleontology, 47: 307-321.

Jenkyns, H. C. 2010.Geochemistry of oceanic anoxic events.Geochemistry, Geophysics, Geosystems, 11: 1-30.

Kennedy, W. J., Gale, A. S., Bown, P. R., Caron, M., Davey, R. J., Gröcke, D. and Wray, D. S. 2000. Integrated stratigraphy across the Aptian-Albian boundary in the Marnes Bleues, at the Col de Pré-Guitterd, Arnayon (Drôme), and at Tortonne (Alpes-deHaute-Provence), France: a candidate global boundary stratotype section and boundary point for the base of the Albian Stage. Cretaceous Research, 21:591-720.

Lees, J. A. 2002. Calcareous nannofossil biogeography illustrates palaeoclimate change in the Late Cretaceous Indian Ocean. Cretaceous Research, 23: 537-634.

Mahanipour, A., Eftekhari, M. and Dastanpour, M. 2018. Barremian-Aptian Calcareous Nannofossil Biostratigraphy in Zagros Basin (West Iran), Tethyan Realm. Stratigraphy and Geological Correlation, 26 (7): 783-797.

Mahanipour, A., Mutterloseb, J. and Eftekharia, M. 2019. Calcareous nannofossils of the Barremian - Aptian interval from the southeastern Tethys (Zagros Basin, West Iran) and their paleoceanographic implications: A record of Oceanic Anoxic Event 1a. Marine Micropaleontology, 149: 64-74.

Mattioli, E., Pittet, B., Bucefalo-Palliani, R., Röhl, H. J., Schmid- Röhl, A. and Morettini, E. 2004. Phytoplankton evidence for the timing and correlation of palaeoceanographical changes during the early Toarcian oceanic anoxic event (Early Jurassic). Journal of the Geological Society, London, 161: 685-693.

Mutterlose, J. 1989. Temperature-controlled migration of calcareous nannofloras in the northwest European Aptian. In: Crux, J.A. and van Heck, S.E. (Eds.), Nannofossils and their applications. Ellis Horwood Limited, Chichester, p 122-144.

Mutterlose, J. 1992. Migration and evolution patterns of floras and faunas in marine Early Cretaceous sediments of NW Europe. Palaeogeography, Palaeoclimatology, Palaeoecology, 94: 261-282.

Mutterlose, J. and Ruffell, A. 1999. Milankovitch-scale palaeoclimate changes in pale-dark bedding rhythms from the Early Cretaceous (Hauterivian-Barremian) of eastern England and northern Germany. Palaeogeography, Palaeoclimatology, Palaeoecology, 154: 133-160. 
Al-Miamary et al.

Mutterlose, J. and Bottini, C. 2013. Early Cretaceous chalks from the North Sea giving evidence for global change. Nature Communications, 4:1686.

Roth, P. H. and Krumbach, K. R. 1986. Middle Cretaceous calcareous nannofossil biogeography and preservation in the Atlantic and Indian Oceans: implications for micropaleontology. Marine Micropaleontology, 10: 235-266.

Sharland, P. R., Archer, R., Casey, D. M., Hall, S. H., Heward, A. P., Horbury, A. D. and Simmons, M. D. 2001. Arabian Plate sequence stratigraphy, Geo Arabia, special publication 2, Gulf Petrolink, Bahrain, 371pp.

Sissingh, W. 1977. Biostratigraphy of Cretaceous calcareous nannoplankton. In: Bolli, H. M., Saunders, J. B. and Perch-Nielsen, K. (eds.) Plankton stratigraphy. Cambridge University Press, Cambridge, 426 pp.

Snyder, D. B. and Barazangi, M.1986. Deep crustal structure and flexure of the Arabian Plate beneath Zagros Collisional Mountain Belt as inferred from gravity observations. Tectonics, 5: 361-373.

Stover, L. E. 1966. Cretaceous coccoliths and associated nannofossils from France and the Netherlands. Micropaleontology, 12: IB-67.

Stampfli, G. M. and Borel, G. D.2002. A plate tectonic model for the Paleozoic and Mesozoic constrained by dynamic plate boundaries and restored synthetic oceanic isochrones. Earth and Planetary Science Letters, 196: 17-33.

Stocklin, J. 1968. Structural history and tectonics of Iran: a review. American Association of Petroleum Geologists Bulletin, 52: 1229-1258.

Street, C. and Bown, P. R. 2000. Palaeobiogeography of Early Cretaceous (BerriasianBarremian) calcareous nannoplankton. Marine Micropaleontology, 39: 265-291.

Talbot, C. J. and Alavi, M. 1996. The past of a future syntaxis across the Zagros. In G.I. Alsop, D.J. Blundell and Davison, I. (Eds.), Salt Tectonics. Geological Society Special Publication, 100: 89-109.

van Bellen, R. C., Dunnington, H. V., Wetzel, R. and Morton, D. M. 1959. Iraq. Lexique Stratigraphique International III, Asie; Fasc. 10 a. Geol. Congr. Comm. Stratigr., Centre Nat. Recherche, Paris, 333 pp.

Watkins, D. K., Cooper, M. J. and Wilson, P. A. 2005. Calcareous nannoplankton response to late Albian oceanic anoxic event 1d in the western north Atlantic. Paleoceanography, 20:PA2010. 


\section{Calcareous nannofossils and chemostratigraphy}

Williams, J. R. and Bralower, T. J. 1995. Nannofossil assemblages, fine fraction isotopes, and the paleoceanography of the Valanginian-Barremian (Early Cretaceous) North Sea Basin. Paleoceanography, 10: 815-839. 
دليل ظاهرة نقص الاوكسجين البحري في شمالي العر اق من متحجر ات النانو الكلسية

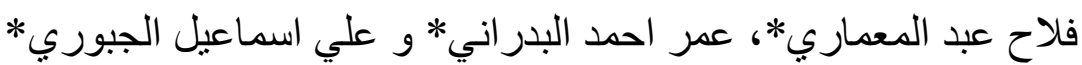

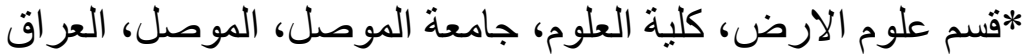

تأريخ الاستلام: 2020/03/11، تأريخ القبول: 2020/05/31، تأريخ النشر: 2020/06/24

$$
\text { الخلاصة }
$$

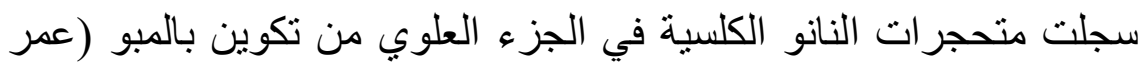

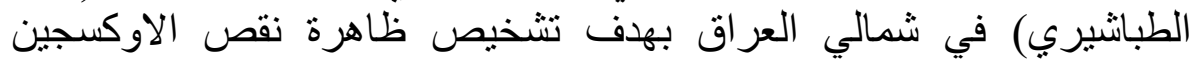

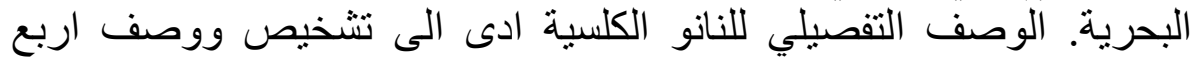

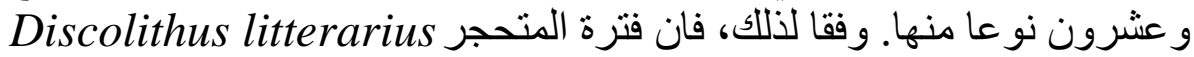
(Górka, 1957)

مجاميع الابنيان المبكر تتميز بشيوع متحجر النانوكونيد، حيث بقل بشكل

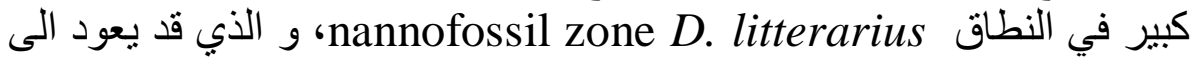
فترة كارثيه مسجلة في السجل الجيولوجي في عمر الابتيان المبكر في اماكن

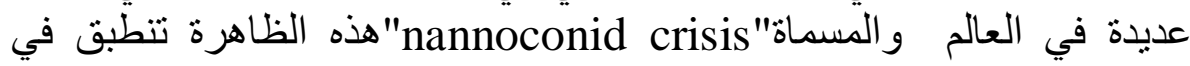

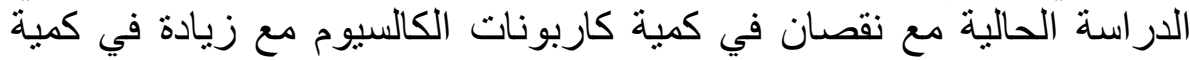

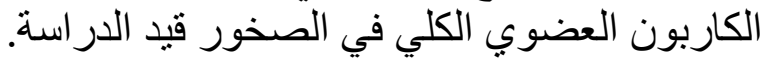

